\title{
RATING SCORE SYSTEM AND ACADEMIC ACHIEVEMENTS OF STUDENTS: EXPERIENCE OF THE CHEMISTRY FACULTY OF THE BELARUSIAN STATE UNIVERSITY
}

\author{
Elena Vasilevskaya, Svyatlana Vashchanka, Natalia \\ Boboriko \\ Belarusian State University, Minsk, Republic of Belarus
}

\begin{abstract}
Improvement of the natural-science higher education, and chemical education in particular, is impossible without evaluation of its quality. One of the criteria of education quality is academic achievements of the students. The experience of using the rating score system for evaluating of the students' academic achievements, accumulated at the Chemistry Faculty of the Belarusian State University (BSU), is discussed. The results of the analysis of students' progress at the Chemistry Faculty of the BSU in the discipline "Inorganic Chemistry" in 2014-2019 showed that the use of the rating system give objective information about the degree of success of students' training.

Keywords: academic achievements, chemistry teaching, education quality, rating score system.
\end{abstract}

\section{Introduction}

For almost 20 years of the implementation of the Bologna process in Europe, significant progress has been made in generation of common terminology, methodology and system of goals and objectives for the formation of general educational and professional competencies settled by educational standards. The European Credit Transfer System (ECTS) and the European Credit system for Vocational Education and Training (NCVET) are widely used in some countries. These systems are designed to ensure transparency, attractiveness and competitiveness of higher education. At the same time different countries use their own systems for evaluating students' academic achievements (Egemberdieva, 2012; Guskey, 2014; Hoge, 1989; Linn, 2001). Grades can be assigned as letters (for example from A to F), as a range (for example from 1 to 10), as a percentage of a total number of questions answered correctly, or as a number out of a possible total (for example out of 20 or 100). Rating score system in a separate subject and an evaluation of students' achievements in general became rather widespread in educational process. In some countries, all grades from all period of education are averaged to create a grade point average (GPA).

The main aim of the research was: to summarize the experience of using the rating score system for evaluating of the students' academic achievements, accumulated at the Chemistry Faculty of the Belarusian State University (BSU), to analyze the relationship of the accumulated rating score with the students' educational achievements, to evaluate the effectiveness and prospects of using of the rating in the educational process in chemistry. 


\section{Research Methodology}

\section{Sample Selection}

The results of academic performance in the discipline "Inorganic Chemistry" in the group of students of the specialty "Chemistry of medicinal compounds" of the Chemistry Faculty of the BSU in 2014-2019 were analyzed.

The interview of 20 lecturers and teachers in 2009, 28 lecturers and teachers in 2012 and 18 lecturers and teachers of higher school in 2019 year was held. Their opinions about problems in using of the rating score system and meaning of this system for students' academic success was ascertained.

\section{Instrument and Procedures}

To solve the assigned tasks the following research methods were used:

- analysis of the scientific publications, documents,

- studying of the academic achievements of students,

- interviews with teachers,

- questionnaire of students to receive a feedback on some problem of using rating score system.

\section{Data Analysis}

The analysis of data obtained was done according to the procedures which were developed in BSU and is described below.

\section{Research Results}

\section{Rating Criteria}

Since the late 1990's, work has been carried out at the Chemistry Faculty of the BSU to develop, test and implement a rating control system for student' academic achievements (Karataeva, 2006, Vasilevskaya, 2009). One of the features of the used rating system is the possibility of varying of its several parameters. These parameters are: the maximum and valid number of points for each control activity, and their time constraints. The value of these parameters is chosen by the department that ensures teaching of the appropriate disciplines. The main parameter of the system is the number "P", which is equal to the sum of the maximum points for control students' activities; it is also equal to the maximum possible current rating. For a particular discipline, the rating can be conducted on any arbitrary scale, but the final rating is expressed in \% from the maximum number of points (that means, on a 100-point scale). Since Belarus adopted a 10-point system of assessment, the student's semester rating is transferred to a 10-point scale with rounding in favor of the student.

Here are some examples of rating calculation.

Example 1. Inorganic Chemistry. Students study this discipline during two semesters. Therefore, the criteria for calculating the rating in each semester are slightly different. 
In the first semester, we take into account the following rating parameters.

Exam for each topic - 30 points. The number of tasks in the exam is determined by their complexity, with each task being estimated from 3 to 10 points. In a variant of work, for example, there may be three tasks of 10 points each or six tasks of 5 points each. This approach allows implementing standards-based grading (SBG) that breaks down the subject matter into smaller "learning targets" (Guskey, 2013). SBG focuses on learning and helps to increase achievement. At the same time, students can choose a work option. In total, there are 6 such exams per semester and the total amount of points is 180 .

Exam for the total course -30 points ( 6 tasks, 5 points for each task)

Active participation in practical classes (seminars) on the topic - from 1 to 5 points. A total of eight topics -50 points.

Work on a laboratory workshop - 50 points (low rating of this type of work is related with the lack of sufficient skills of work in chemical laboratory of first-year students).

Maximum number of the points for the semester is 370 .

In the second semester for the same discipline, the approach to calculating rating points is changing; the importance of a laboratory workshop is growing. Students perform individual tasks on the synthesis of inorganic compounds by known methods (a total of 8 syntheses of 10 points each). The test synthesis is provided at the end of the semester: students independently find the method, discuss it with the teacher, perform the synthesis and study the properties of the obtained substance ( 20 points). The laboratory workshop is estimated at 100 points.

Examination in this semester is estimated at 160 points, participation in practical classes (seminars) -20 points, colloquiums -40 points. Maximum number of the points for this semester is 320 . Students can receive an additional 20 points for participating in the conference.

\section{Example 2. Professional communication in Chemistry.}

Work in group (attendance of the classes, work at seminars, participation in the discussions etc.) -20 points.

Writing of a $\mathrm{CV}-10$ points.

Preparation and justification of a scientific project -30 points.

Making a bibliographic list of references -10 points.

Abstract of a scientific article in two languages (Russian, English) - 10 points.

Summary of a scientific article in three languages (Russian, Belorussian, English) 10 points.

Preparation of a presentation -10 points.

Maximum number of the points for the semester is 100 .

\section{Student's Semester Rating, Final Grade and GPA}

The final grade for the discipline is an integral factor, which is formed on the basis of the student's semester rating and exam mark. The contribution of the rating to the final mark in the discipline may vary by the decision of the department depending on the specifics of the academic discipline and may range from 30 to $60 \%$.

For example, in the discipline "Inorganic Chemistry" a semester rating is included in the final mark with 0.3 coefficients, and the mark for the exam is with 0.7 coefficients. The final mark for the discipline is determined by the equation:

$$
\mathrm{FM}=\mathrm{P} \times 0.3+\mathrm{E} \times 0.7
$$

where $\mathrm{P}$ is the current rating and $\mathrm{E}$ is mark for the exam in a10-point scale. 
It is important to note that if a student receives an unsatisfactory grade for an answer at the exam (below 4 points from 10), current rating becomes equal to zero and is not taken into account in the final grade.

As an example, we present the results of the analysis of academic performance in the discipline "Inorganic Chemistry" in the group of students of the specialty "Chemistry of medicinal compounds" of the Chemistry Faculty of the BSU. The table 1 shows the rating score (P), the mark for the exam (E) and the final mark (FM) in Inorganic Chemistry, obtained by them in spring 2017, as well as the GPA based on six passed exam sessions.

Table 1. Rating score for group of students of the specialty "Chemistry of medicinal compounds".

\begin{tabular}{|c|c|c|c|c|c|}
\hline \multirow{2}{*}{ No. } & Name & \multicolumn{2}{|c|}{ Inorganic Chemistry, spring 2017 } & \multirow{2}{*}{$\begin{array}{c}\text { GPA based on six } \\
\text { passed exam sessions } \\
\text { (June 2019) }\end{array}$} \\
\cline { 3 - 5 } & & P & E & FM & 6.6 \\
\hline 1 & Anna B. & 7 & 5 & 6 & 8.9 \\
\hline 2 & Andrej B. & 9 & 9 & 9 & 6.5 \\
\hline 3 & Margarita B. & 6 & 4 & 5 & 7.3 \\
\hline 4 & Olga V. & 7 & 7 & 7 & 9.2 \\
\hline 5 & Anna V. & 9 & 9 & 9 & 7.2 \\
\hline 6 & Anna G. & 7 & 6 & 6 & 6.5 \\
\hline 7 & Alesia G. & 8 & 7 & 7 & expelled \\
\hline 8 & Karolina D. & 5 & 5 & 5 & 8.0 \\
\hline 9 & Victoria D. & 8 & 9 & 9 & 6.0 \\
\hline 10 & Andrej Z. & 9 & 9 & 9 & 6.1 \\
\hline 11 & Dmitry Z. & 7 & 4 & 5 & 5.8 \\
\hline 12 & Margarita K. & 5 & 5 & 5 & 8.8 \\
\hline 13 & Felix L. & 6 & 7 & 7 & 6.7 \\
\hline 14 & Eugenia L. & 7 & 9 & 9 & 5.9 \\
\hline 15 & Elena M. & 7 & 7 & 7 & 6.8 \\
\hline 16 & Anastasia P. & 6 & 5 & 5 & 5.5 \\
\hline 17 & Natalia S. & 7 & 7 & 7 & expelled \\
\hline 18 & Yana T. & 5 & 4 & 4 & 5.8 \\
\hline 19 & Aleksandra S. & 6 & 4 & 5 & 6 \\
\hline 20 & Ksenia S. & 5 & 6 & 6 & \\
\hline
\end{tabular}

As follows from the data above, most of the students have a good correlation between the current rating score and the grade given by the examiner ( $\mathrm{P}-\mathrm{E} \leq 1)$. For some students (Margarita B., Dmitry Z., Aleksandra S.) exam mark turned out to be significantly lower than the current rating, but the presence of a higher rating score allowed slight increasing of the final mark. 


\section{Opinion of Students}

In an interview in May 2019 3-years students of the specialty "Chemistry of medicinal compounds" noted that:

- the rating system stimulates to work systematically,

- enhances the objectiveness of the final mark,

- helps to find gaps in education before the exam,

- reduces anxiety and psychological tension during the preparation for the exam.

\section{Opinion of Lecturers}

In an interview the lecturers were asked to choose merits and drawbacks of the rating system. Interviewing was held in 2009, 2012 and 2019. The results and trends of the change of lecturers' answers are presented in Figures 1 and Figures 2.

Merits of the method, $\%$ of the interviewed

Provides a unified approach to all students

Increases student activity

Objectively ranks students according to their knowledge

Stimulates regular work of students on the material being studied

Eliminates random exam grades

Promotes individualization of the educational process

Increases student confidence in the final grade

Provides end-to-end study planning throughout the course

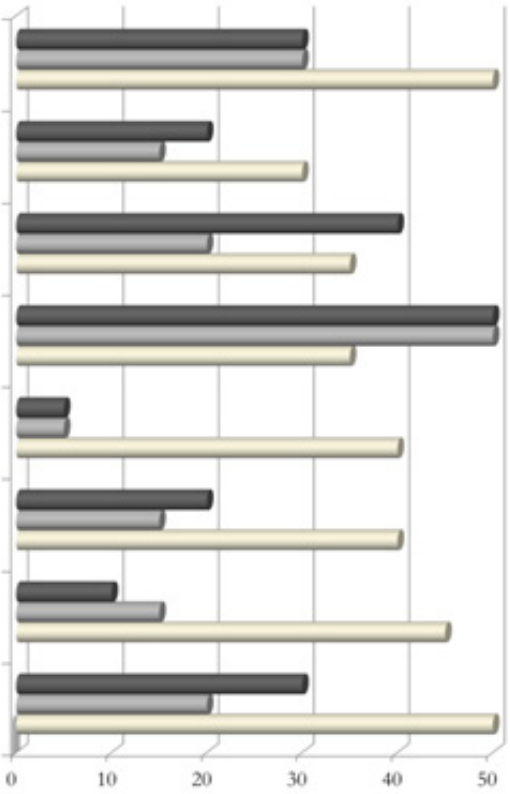

Figure 1. The opinion of teachers about the merits of the rating score system. 


\section{Drawbacks of the method, $\%$ of the interviewed}

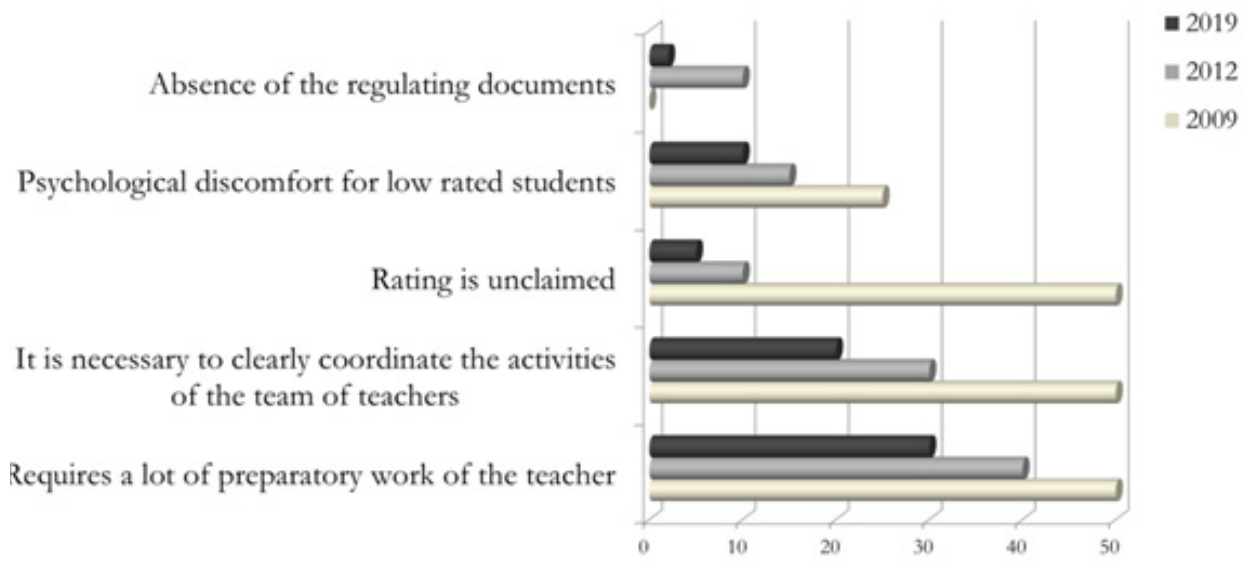

Figure 2. The opinion of teachers about the drawbacks of the rating score system.

Interesting turns out to be comparison of the rating score and the average grade point (table1): the average grade correlates well with the rating mark that reflects the student's work in the semester than with the exam mark. Two possible reasons can be noted here: the subjective demands of a particular examiner, when the grades in a discipline become slightly lower than the average weighted performance; or a decrease in students' excitement at the exams by the end of the third year, which leads to a gradual leveling of their exam marks with rating points of the current knowledge shown in a more relaxed atmosphere.

Similar rating calculation systems are used to assess students' academic achievements in other disciplines studied at the Faculty of Chemistry (Kondrev, 2018, Savitskaya, 2006), and generally correspond to the Regulation on the rating system for assessing students' knowledge of the discipline at BSU (https://www.bsu.by/main.aspx?guid=13831).

It should be noted that rating can also be determined by:

- reflecting student performance in all subjects studied in this semester;

- for a cycle of related disciplines studied during a certain period;

- reflecting the performance of the student as a whole during a period or for the entire duration of the training (integrated rating).

At the same time, the integrated rating can be expressed as the GPA.

As can be seen from the results of the lecturers' interviews (fig. 1 and fig. 2), their opinion regarding the use of the rating system to assess students' academic achievements has changed throughout the study. In an interview in 2009-2012, lecturers focused on the difficulties associated with coordinating of the approaches and educational methods, developing of regulatory documents, and preparing of a single bank of tasks. In recent years, the merits of the rating system are noted more often, in particular, ensuring of end-to-end planning of academic work on the discipline, the ability to adjust the speed of studying of certain topics, the ability of quick respond to questions that are not well understood by students, etc.

The rating system for assessing academic achievements of students used at the Faculty of Chemistry of the BSU is in constant development. Recently, the issue of an 
approach to assessing students' work using active innovative teaching methods (Bryan, 2019, Sambell, 2013) requires further improvement.

The next step in the development of the system used will be to define a feedback procedure that allows you to evaluate the quality of implementation educational programs at the faculty in general and the use of innovative educational technologies in particular. The experience gained in the countries of the European Union (Kwiatkowski, 2018; Measuring Innovation in Education 2019) will be very useful here.

\section{Conclusions}

The experience of the Chemistry Faculty of the BSU showed that the use of the rating system for evaluating of academic achievements requires from the students to work on the course material continually, rather than occasionally; stimulates more intensive work of strong students, introducing an element of competition, on the one hand, and, on the other, contributes to greater confidence during final control for weak students who regularly work during the semester.

The introduction of a rating system for evaluating academic achievements is effective, taking into account the incentives, which it provides for students: differentiated and personalized scholarships, allowances for scholarships, grants for training; advantage in the selection of disciplines of choice with a limited number of places; recommendations for foreign academic trips; placement to a postgraduate course and the benefits when choosing a job.

\section{References}

Bryan, C., \& Clegg, K. (2019). Innovative assessment in higher education: A handbook for academic practitioners ( 2 nd ed.). Routledge.

Egemberdieva, G. A., Smagulova, D. A., Vasilevskaya, E. I., \& Khaletsky, V. A. (2012). Reytingovaya sistema kontrolya i otsenki uchebnykh dostizheniy v vuzakh Kazakhstana i Belarusi [Rating system of monitoring and evaluation of educational achievements in universities of Kazakhstan and Belarus]. In. Innovative technologies in the system of additional education for adults: A collection of scientific articles (pp. 55-61). Brest.

Guskey, T. R., Roy, P., \& Von Frank, V. (2014). Reaching the highest standard in professional learning: Data. Corwin Press \& Learning Forward.

Guskey, T. R., \& Jung, L. A. (2013). Answers to essential questions about standards, assessments, grading, \& reporting. Corwin Press.

Hoge, R. D., \& Coladarci, T. (1989). Teacher-based judgments of academic achievement: A review of literature. Review of Educational Research, 59(3), 297-313. https://doi.org/10.3102\% 2F00346543059003297

Karataeva, T. P. (2006). Reytingovaya otsenka uchebnoy raboty studentov kak faktor povysheniya kachestva obrazovaniya [Rating evaluation of students' academic work as a factor in improving the quality of education]. In: Evaluation: Educational opportunities: A collection of scientific method. Articles. Issue 4 (pp. 107-115). Minsk.

Kondrev, V. S., Onishchuk, A. V., Andronchik, K. A., \& Melsitova, I. V. (2018). O postroyenii reytingovoy sistemy otsenki rezul'tatov uchebnoy deyatel'nostipo distsipline «Analiticheskaya khimiya» dlya studentov khimicheskikh spetsial'nostey [On the construction of a rating system for assessing the results of educational activities in the discipline "Analytical Chemistry" for students of chemical specialties]. In: Actual problems of chemical education in secondary and higher education: A collection of scientific articles (pp. 240-242). Vitebsk. 
Kwiatkowski, M. (2018). Krytyczna analiza system zapewnieniaj akości kształceniana Wydziale Chemii Uniwersytetu Gdańskiego. In DidSci Plus - Research in Didactics of Science PLUS. Proceedings of the International Conference (pp. 241-247). Charles University.

Linn, R. L. (2001). A century of standardized testing: Controversies and pendulum swings. Educational Assessment, 7(1), 29 - 38. https://doi.org/10.1207/S15326977EA0701 4.

Measuring Innovation in Education 2019. https://www.oecd-ilibrary.org/education/measuringinnovation-in-education-2019_9789264311671-en;jsessionid=psESXWwqC_ I7DJjaoXEbN6dU.ip-10-240-5-17.

Sambell, K., McDowell, L., \& Montgomery, C. (2013). Assessment for learning in higher education. Routledge.

Savitskaya, T. A., \& Charapennikau, M. B. (2006). Kolichestvennaya storona konstruirovaniya morfologii reytinga [Quantitative side of creating rating morphology]. Sviridov Readings, 3, $247-253$.

Vasilevskaya, E. I., Karataeva, T. P., \& Sviridova, T. V. (2009). Reytingovaya sistema otsenki dostizheniy $\mathrm{v}$ uchebnom protsesse: plyusy i minusy [Rating system for assessing achievements in the educational process: Pros and cons]. In TekhnoObraz'2009: Materials of the International scientific and practical conference (pp. 256-259). Grodno.

Received 21 October 2019; Accepted 29 December 2019

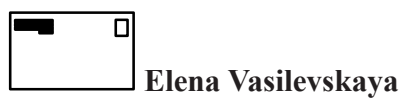

$\mathrm{PhD}$, Associate Professor, Faculty of Chemistry, Belarusian State University, Minsk, Republic of Belarus.

E-mail: evas@tut.by

Website: https://scholar.google.com/citations?user=XqBA1QkAAAAJ\&hl=th

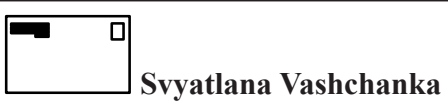

$\mathrm{PhD}$, Associate Professor, Belarusian State University, Minsk, Republic of Belarus.

E-mail: vaschenko@imaph.bas-net.by

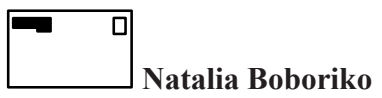

$\mathrm{PhD}$, Associate Professor, Faculty of Chemistry, Belarusian State University, Minsk, Republic of Belarus.

E-mail: boboriko@bsu.by

Website: https://www.researchgate.net/profile/Natalia_Boboriko 